\title{
Larval salinity tolerance of the South American salt-marsh crab, Neohelice (Chasmagnathus) granulata: physiological constraints to estuarine retention, export and reimmigration
}

\author{
Klaus Anger · Eduardo Spivak · Tomás Luppi • \\ Claudia Bas $\cdot$ Deborah Ismael
}

Received: 14 March 2007 / Revised: 17 July 2007 / Accepted: 17 July 2007 / Published online: 15 August 2007

(C) Springer-Verlag and AWI 2007

\begin{abstract}
The semiterrestrial crab Neohelice (=Chasmagnathus) granulata (Dana 1851) is a predominant species in brackish salt marshes, mangroves and estuaries. Its larvae are exported towards coastal marine waters. In order to estimate the limits of salinity tolerance constraining larval retention in estuarine habitats, we exposed in laboratory experiments freshly hatched zoeae to six different salinities $(5-32 \%$ ) . At $5 \%$, the larvae survived for a maximum of 2 weeks, reaching only exceptionally the second zoeal stage, while $38 \%$ survived to the megalopa stage at $10 \%$. Shortest development and negligible mortality occurred at all higher salt concentrations. These observations show that the larvae of $N$. granulata can tolerate a retention in the mesohaline reaches of estuaries, with a lower limit of $c a$. 10-15\%o. Maximum survival at 25\% suggests that polyhaline conditions rather than an export to oceanic waters are optimal for successful larval development of this species. In another experiment, we tested the capability of the last
\end{abstract}

Communicated by H.-D. Franke.

K. Anger $(\bowtie)$

Biologische Anstalt Helgoland (BAH),

Stiftung Alfred-Wegener-Institut für Polar- und

Meeresforschung, 27498 Helgoland, Germany

e-mail: klaus.anger@awi.de

E. Spivak · T. Luppi · C. Bas

Departamento de Biología, Facultad de Ciencias Exactas y

Naturales, Universidad Nacional de Mar del Plata,

and Consejo Nacional de Investigaciones Científicas y Técnicas

(CONICET), C.C. 1245, 7600 Mar del Plata, Argentina

D. Ismael

Faculdade Evangélica do Paraná (FEPAR),

Rua Padre Anchieta, 2770, Curitiba,

PR CEP 80730-000, Brazil zoeal stage (IV) for reimmigration from coastal marine into brackish waters. Stepwise reductions of salinity during this stage allowed for moulting to the megalopa at $4-10 \%$. Although survival was at these conditions reduced and development delayed, these results suggest that already the zoea-IV stage is able to initiate the reimmigration into estuaries. After further salinity reduction, megalopae survived in this experiment for up to $>3$ weeks in freshwater, without moulting to juvenile crabs. In a similar experiment starting from the megalopa stage, successful metamorphosis occurred at 4-10\%o, and juvenile growth continued in freshwater. Although these juvenile crabs showed significantly enhanced mortality and smaller carapace width compared to a seawater control, our results show that the late larval and early juvenile stages of $N$. granulata are well adapted for successful recruitment in brackish and even limnetic habitats.

Keywords Larval development · Crab · Varunidae . Export strategy $\cdot$ Salinity stress .

Ontogeny of osmoregulation $\cdot$ Estuarine $\cdot$ Recruitment

\section{Introduction}

The varunid crab Neohelice granulata (Dana 1851) (=Chasmagnathus granulata; for recent taxonomic revision, see Sakai et al. 2006) is a highly dominant component of the macrofauna in South American salt marshes, estuaries and mangroves, ranging from northern Patagonia, Argentina, through Uruguay, to Rio de Janeiro, Brazil (e.g. Boschi 1964; Boschi et al. 1992; Ruffino et al. 1994; Bas et al. 2005). Due to its intense burrowing and omnivorous feeding activities, this abundant semiterrestrial species shapes regional habitat and community structures in the intertidal 
and supratidal coastal fringe, exerting significant effects on sediments, plants, benthic invertebrates, fish and migratory shore birds (Iribarne et al. 2000, 2005; Daleo et al. 2003; Bortolus et al. 2004; Martinetto et al. 2005, 2007; Botto et al. 2005, 2006 and earlier papers cited therein).

Tolerating a wide range of salinities from freshwater to hypersaline conditions, as well as hypoxic conditions, $N$. granulata has become a standard model for studies of physiological and biochemical adaptations to transitional environments between the sea, freshwater and land (e.g. Castilho et al. 2001; Luquet et al. 2002; Halperin et al. 2004; Maciel et al. 2004; de Oliveira et al. 2005; Schein et al. 2005b). Moreover, easy access, suitable size and high-stress tolerance made this species of crab a frequently used invertebrate model for experimental studies of metabolic physiology (e.g. Oliveira et al. 2004; Schein et al. 2005a; Marqueze et al. 2006), pollution effects (e.g. Abigail et al. 2003; Medesani et al. 2004a, b; Menone et al. 2004), and of the neurological and molecular basis of behaviour, learning and memory (e.g. Delorenzi et al. 2000; Locatelli et al. 2001; Tomsic et al. 2003; Romano et al. 2006; Oliva et al. 2007).

While the benthic juvenile and adult life-history stages of $N$. granulata are adapted to semiterrestrial, brackish, hypersaline and transitorily occurring freshwater conditions (e.g. Ituarte et al. 2004; Bas et al. 2007), its planktonic larval stages appear to be unable to survive and develop in the physically extreme or unpredictable habitats of the adults. Field observations (Anger et al. 1994) have shown that the zoeae hatch within the adult habitats (i.e. no reproductive migrations of ovigerous females occur), preferably at nocturnal high tides. Outflowing ebb currents transport the freshly hatched larvae rapidly towards coastal marine waters with more stable and, on average, higher salinities, while the nocturnal timing of hatching may reduce mortality by pelagic predation, e.g. by visually oriented and planktivorous estuarine fish (Anger et al. 1994).

These are typical patterns of an "export strategy" (Strathmann 1982). It represents a life-history adaptation to estuarine conditions commonly found in decapod crustaceans and other benthic invertebrates with complex life cycles (Anger 2001, 2003). This strategy has mostly been explained as a mechanism allowing for an avoidance of physiologically stressful hypo-osmotic conditions during the sensitive larval phase; additionally, it may reduce pelagic predation in estuaries (see Morgan 1995, and earlier papers cited therein). Neohelice granulata may thus be considered as a typical example, or a model, for an estuarine export strategy.

In order to estimate (1) the limits and potential effects of larval retention within brackish habitats of $N$. granulata, we compare in the present laboratory study larval survival and development from hatching through successive zoeal stages during continuous exposure to six different constant salinities (5-32\%o). In another set of experiments, we (2) evalu- ate the capability of the last zoeal stage (IV) to develop to the megalopa stage during an experimentally simulated reimmigration from coastal marine waters to brackish or freshwater habitats. Finally, we identify (3) the tolerated limits for megalopal reimmigration, metamorphosis in brackish water and subsequent juvenile growth in freshwater, experimentally simulating an exposure to decreasing salinities beginning after the moult to the megalopa stage.

\section{Materials and methods}

Origin of materials, larval rearing

Adult $N$. granulata were obtained from the intertidal zone of the brackish coastal lagoon Mar Chiquita, Argentina $\left(37^{\circ} 44^{\prime} \mathrm{S} ; 57^{\circ} 25^{\prime} \mathrm{W}\right.$; for habitat characterization, see Spivak et al. 1994), transported to the Helgoland Marine Biological Station (Germany), and subsequently maintained under controlled laboratory conditions at a temperature of $18 \pm 1^{\circ} \mathrm{C}$, a salinity of $32 \pm 1 \%$ and an artificial $12: 12 \mathrm{~h}$ light : dark cycle. Frozen isopods (Idotea spp.), mussels (Mytilus edulis) and shrimp (Crangon crangon) from the North Sea were given as food (for further details, see Gebauer et al. 1998; Giménez 2002).

All larval rearing experiments were run at the same conditions of temperature and light, using filtered (Orion, mesh size: $1 \mu \mathrm{m})$ seawater from the North Sea $(32 \%)$. The required test salinities were obtained by dilution with appropriate amounts of desalinated tap water and checked with a temperature-compensated electric probe (WTW, Weilheim, Germany) to the nearest $0.1 \%$. During the experiments, larvae were reared individually in numbered glass vials with $30 \mathrm{ml}$ (zoeal stages) or in plastic bowls with $100 \mathrm{ml}$ water (megalopa and juvenile stages). Larvae required for experiments with later beginning exposure to different salinites (from the zoea IV or megalopa stage; see below), were obtained by mass rearing in unaerated glass bowls (400 ml, 50 zoeae per bowl) at $32 \%$ ond in otherwise identical conditions. In the megalopa and juvenile crab stages, a piece of nylon gauze ( $0.2 \mathrm{~mm}$ mesh size) was provided as an artificial substrate. In daily intervals, water was changed, the larvae were checked for moults or mortality, and fresh food was provided (newly hatched San Francisco Bay Brand Artemia sp. nauplii, $\sim 10 / \mathrm{ml})$. The larval stages were identified using the morphological description by Boschi et al. (1967).

Experiment 1: exposure to different constant salinities from hatching

In this experiment, we tested for tolerated salinity limits allowing for larval retention and successful development in 
estuarine environments, where conspecific adult populations live. Within maximally $12 \mathrm{~h}$ after hatching, 300 actively swimming zoea-I larvae from the same hatch were individually transferred to numbered vials with $c a .30 \mathrm{ml}$ filtered seawater. The experimental exposure to six different test salinities $(5,10,15,20,25,32 \%$; initial $n=50$ zoeae per treatment) began either immediately $(25,32 \%$ ) or after stepwise acclimation within maximally $8 \mathrm{~h}$, reducing the salt concentration from $25 \%$ in steps of $5 \%$ every $2 \mathrm{~h}$, until the final salinity was reached. The condition with a constant salinity of $32 \%$ is hereafter referred to as "seawater control".

We terminated this experiment already in the megalopa, because high mortality (caused by a factor other than salinity) occurred in this stage. As a consequence, no statistically relevant data of survival or development duration through the megalopa stage became available from this experiment. Likewise, we excluded from our data a few exceptional cases occurring at low salinities (three individuals at $10 \%$, one at $15 \%$ ), where zoea-IV larvae developed to a zoea- $\mathrm{V}$ stage and not directly to a megalopa. This longer developmental pathway in N. granulata was morphologically described by Pestana and Ostrensky (1995), and factors favouring its occurrence as well as consequences for later larval and juvenile development were studied in detail by Giménez and Torres (2002), Giménez and Anger (2003) and Giménez et al. (2004).

Experiments 2 and 3: exposure to decreasing salinities from the zoea-IV or megalopa

Although the reimmigration from coastal marine to estuarine and oligohaline waters presumably occurs in the megalopa and/or in early juvenile crab stages, a beginning of return already in late zoeal stages is also conceivable, as these stages show mostly demersal behaviour, which may favour an onshore transport with tidal bottom currents (Anger 2001). We therefore tested in Experiments 2 and 3 the tolerance of stepwise salinity reductions during both the zoea-IV and the megalopa stages (for experimental design, see Table 1).

Experiment 2 was started with 200 mass-reared larvae (originating from a different hatch than that used for Exp. 1 ), which reached on the same day the zoea-IV stage. It comprised a seawater control (constant $32 \%$; group A) and three treatments with different schedules of stepwise salinity decrease, allowing for gradual acclimation to hypoosmotic conditions including freshwater (groups B-D; Table $1 ; n=50$ larvae per group). In these treatments, the salinities decreased rapidly within 10 days to 8,6 and $4 \%$, respectively, followed by further reduction at slower rates. The final transfer to freshwater occurred on days 22, 20 and 18 , respectively (treatments B, C, D).
Table 1 Experiments 2, 3, experimental design: timing and extent of stepwise salinity reductions (B-F, treatments), beginning from the zoea-IV or megalopa stage, respectively; treatment A (not shown): constant 32\%o (seawater control)

\begin{tabular}{|c|c|c|c|c|c|c|c|c|}
\hline \multirow[b]{3}{*}{ Day/Treatment } & \multirow{2}{*}{\multicolumn{3}{|c|}{$\begin{array}{l}\text { Experiment } 2 \\
(\text { Zoea IV) } \\
\text { Salinity }(\% o)\end{array}$}} & \multirow{2}{*}{\multicolumn{5}{|c|}{$\begin{array}{l}\text { Experiment } 3 \\
\text { (Megalopa) } \\
\text { Salinity }(\% o)\end{array}$}} \\
\hline & & & & & & & & \\
\hline & B & $\mathrm{C}$ & $\mathrm{D}$ & B & $\mathrm{C}$ & $\mathrm{D}$ & E & $\mathrm{F}$ \\
\hline 1 & 32 & 25 & 25 & 32 & 32 & 25 & 32 & 32 \\
\hline 2 & 32 & 20 & 20 & 32 & 25 & 25 & 32 & 32 \\
\hline 3 & 25 & 20 & 15 & 25 & 25 & 20 & 32 & 32 \\
\hline 4 & 20 & 15 & 10 & 25 & 20 & 20 & 32 & 32 \\
\hline 5 & 20 & 15 & 10 & 25 & 20 & 15 & 32 & 32 \\
\hline 6 & 15 & 10 & 8 & 20 & 15 & 15 & 32 & 32 \\
\hline 7 & 15 & 10 & 8 & 20 & 15 & 10 & 20 & 32 \\
\hline 8 & 10 & 8 & 6 & 20 & 15 & 10 & 15 & 32 \\
\hline 9 & 10 & 8 & 6 & 15 & 10 & 10 & 10 & 10 \\
\hline 10 & 8 & 6 & 4 & 15 & 10 & 8 & 8 & 6 \\
\hline 11 & 8 & 6 & 4 & 15 & 10 & 8 & 6 & 4 \\
\hline 12 & 6 & 4 & 3 & 10 & 8 & 8 & 4 & 2 \\
\hline 13 & 6 & 4 & 3 & 10 & 8 & 6 & 2 & 1 \\
\hline 14 & 4 & 3 & 2 & 10 & 8 & 6 & 1 & 0 \\
\hline 15 & 4 & 3 & 2 & 8 & 6 & 6 & 0 & \\
\hline 16 & 3 & 2 & 1 & 8 & 6 & 4 & & \\
\hline 17 & 3 & 2 & 1 & 8 & 6 & 4 & & \\
\hline 18 & 2 & 1 & 0 & 6 & 4 & 4 & & \\
\hline 19 & 2 & 1 & & 6 & 4 & 3 & & \\
\hline 20 & 1 & 0 & & 6 & 4 & 3 & & \\
\hline 21 & 1 & & & 4 & 3 & 3 & & \\
\hline 22 & 0 & & & 4 & 3 & 2 & & \\
\hline 23 & & & & 4 & 3 & 2 & & \\
\hline 24 & & & & 3 & 2 & 2 & & \\
\hline 25 & & & & 3 & 2 & 1 & & \\
\hline 26 & & & & 3 & 2 & 1 & & \\
\hline 27 & & & & 2 & 1 & 1 & & \\
\hline 28 & & & & 2 & 1 & 0 & & \\
\hline 29 & & & & 2 & 1 & & & \\
\hline 30 & & & & 1 & 0 & & & \\
\hline 31 & & & & 1 & & & & \\
\hline 32 & & & & 1 & & & & \\
\hline 33 & & & & 0 & & & & \\
\hline
\end{tabular}

Experiment 3 started with 250 mass-reared larvae from the same hatch that had been used also for Exp. 2, using only individuals that moulted on the same day from the zoea-IV to the megalopa. Since almost no mortality occurred in the individually reared seawater control group (A) of Exp. 2, and the larvae originated from the same hatch, we continued to use this group also as a seawater control (A) in Exp. 3 (initial $n=47$ megalopae). Besides 
this control, the experiment comprised five treatments (BF) with differential rates of decreasing salinity and a final transfer to freshwater, occurring on days 33, 30, 28, 15 and 14 , respectively (Table $1 ; n=50$ larvae per group). In treatments $\mathrm{E}$ and $\mathrm{F}$, we tested if several (8-10) days of initial development in seawater $(32 \%$ ), i.e. without an early occurrence of hypo-osmotic stress, provides the megalopa with sufficient strength allowing for a rapid subsequent reimmigration to oligohaline water, reaching freshwater conditions near metamorphosis to the first juvenile crab stage.

Besides mortality and development duration, we used in Experiment 3 juvenile body growth also as an additional criterion for the evaluation of salinity effects. Carapace width $(\mathrm{CW})$ of young crabs was measured to the nearest $0.01 \mathrm{~mm}$ under a Leica MZ8 stereomicroscope equipped with a calibrated eye piece micrometer.

\section{Statistical methods}

Statistical analyses following standard techniques (Sokal and Rohlf 1995) were made using a JMP software package (Version 5.1.2; SAS Institute Inc., Caly, NC, USA). Effects of experimental treatments on development duration were tested using non-parametric one-way ANOVA (Kruskal Wallis $H$-tests), as some data did not comply with the prerequisites of normality or homogeneity of variance (Kolmogorov-Smirnov and Levene test, respectively). A posteriori comparisons among treatments were carried out with Student-Newman-Keuls (SNK) tests. An RxC test of independence was used to analyse effects of treatments on mortality (Sokal and Rohlf 1995). Average values are consistently given as arithmetic mean \pm one standard deviation (SD).

\section{Results}

\section{Experiment 1}

When larvae of $N$. granulata were reared from hatching at various constant salinities ranging from 5 to $32 \%$, strong effects of osmotic stress on survival were observed at 5 and $10 \%$, while no or only very little mortality was observed at all higher salinities (Fig. 1, upper graph). Most of this mortality already occurred during the first zoeal stage, with $86 \%$ dying at a salinity of $5 \%$, and $52 \%$ at $10 \%$. An enhanced mortality occurred in these two treatments also in the zoea-II stage, where all remaining zoeae (14\%) died at the lowest salinity, and another $8 \%$ at $10 \%$.

Cumulative rates of zoeal mortality (stages I-IV combined) indicate that a slightly reduced salinity of $25 \%$ represents an optimal condition for larval survival to the megalopa stage ( $100 \%$ survival), while cumulative mortalities of $8-12 \%$ occurred at 15,20 and $32 \%$. Highest zoeal mortalities were observed at 5 and $10 \%$ (100 and 62\%, respectively). In addition, the two lowest salinities allowing for successful development from hatching through the zoea-IV stage (10 and 15\%o) were the only treatments in which a long developmental pathway with a zoea-V stage occurred, although only exceptionally (with three and one individuals, respectively).

The patterns observed in zoeal development duration matched those in mortality (Fig. 1). The two lowest salinities $(5,10 \%$ o caused consistently a strong and highly significant developmental delay, while all other conditions allowed for shorter and generally similar times of development through the successive zoeal stages. Interestingly, the first zoeal stage showed a slight but statistically significant delay in seawater $(32 \%$ ) compared to the treatment with $25 \%$. In the subsequent zoeal stages, however, this difference disappeared. In the last zoeal stage (IV), the duration of development showed a slighly decreasing tendency with increasing salinity, so that significantly shorter development times were observed at 25-32\%o compared to 10 $15 \%$, and an intermediate value at $20 \%$.


Fig. $1 N$. granulata, Experiment 1. Upper graph: cumulative mortality ( $\%$, initial $n=50$ ) from hatching through zoeal stages I-IV to the megalopa. Lower graph: development time (days; mean \pm SD) through successive zoeal stages. Different letters above columns indicate significant differences between salinity treatments 


\section{Experiment 2}

When larvae were reared in seawater from hatching until they reached the zoea-IV stage, and then exposed to various salinity treatments, the seawater control (larvae remaining at $32 \%$, treatment A) allowed for highest survival and shortest development to the megalopa stage (Fig. 2). In treatment $\mathrm{B}$, moulting to the megalopa occurred on days 8 and 9 of the experiment, 1 day later than in the seawater control. Salinity was at that time reduced to $10 \%$ (Table 1). This condition allowed for almost equally high survival to the megalopa as in the seawater control (90\% vs. 94\%), but with a significant delay in the time of moulting (Fig. 2).

Treatment C implied a faster reduction of salinity (Table 1). When moulting to the megalopa stage occurred (also here on days 8-9), the salinity had decreased to $8 \%$. This condition caused both a significant reduction of survival (64\%) and a further delay of development (Fig. 2). In treatment $\mathrm{D}$, moulting to the megalopa occurred on days 911 , when salinity had been reduced to a level of $6-4 \%$ o (Table 1). Survival to the megalopa was in this case reduced to $60 \%$ (not significantly different from treatment C), while the time of development showed an additional significant delay (Fig. 2).
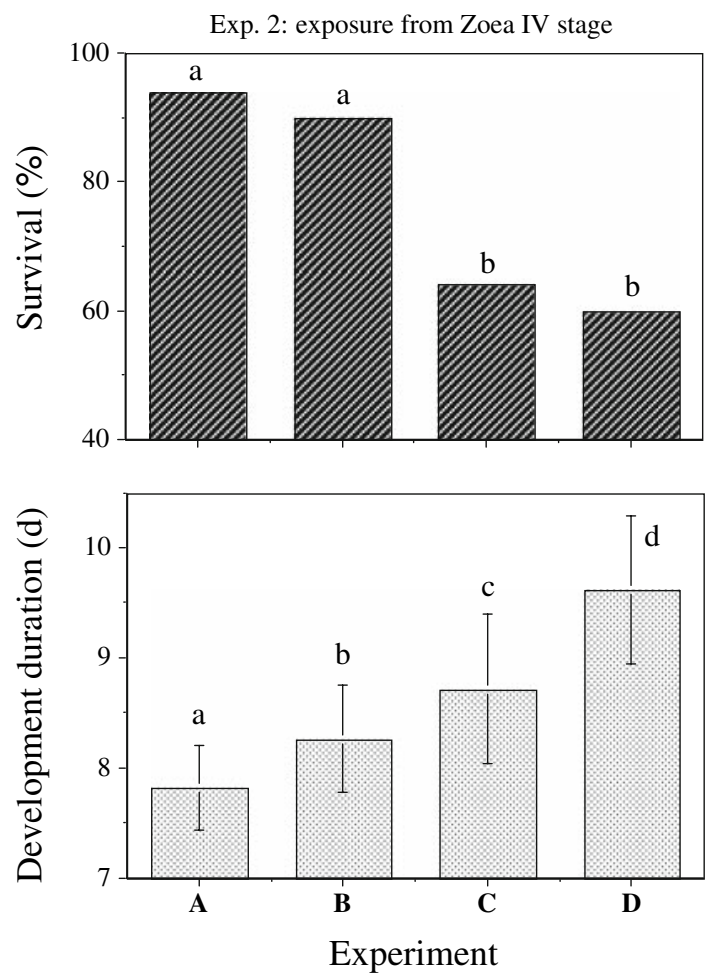

Fig. 2 N. granulata, Experiment 2. Upper graph: survival of zoea-IV larvae to the megalopa stage (\%, initial $n=50$ ). Lower graph: development time through the zoea-IV stage (days; mean \pm SD). Different letters above columns indicate significant differences between salinity treatments
Although $60-90 \%$ of the larvae in treatments B-D developed successfully to the megalopa stage, non of these survivors was subsequently able to pass also through metamorphosis to the first juvenile crab stage (Fig. 3). Yet, it is noteworthy that the megalopae lived in these treatments for up to 1 month without moulting (maximum: 32 days; treatment B), surviving for up to 24 days in freshwater. In treatments $\mathrm{C}$ and $\mathrm{D}$, the time of megalopal survival was clearly shorter (maximally 26 and 14 days, with up to 15 and 8 days, respectively, in freshwater; Fig. 3), corresponding with lower survival and delayed development through the zoea-IV stage. When the last megalopae died, 40 days after the beginning of the experiment (treatment B), the individuals in the seawater control (A) were already beginning to moult from the second to the third juvenile crab stage (Fig. 3). Juvenile growth was followed until the young crabs in the seawater control were moulting from the fifth to the sixth juvenile instar (Fig. 3).

\section{Experiment 3}

Metamorphosis from the megalopa to the first juvenile crab instar began in this experiment on day 14 (treatment C) or 12 (all other groups including the seawater control), while salinity was reduced to levels between 4 and $10 \%$ o (Table 1). No survival through metamorphosis occurred in treatment $\mathrm{F}$, where a direct transfer from 32 to $10 \%$ caused an immediate and almost complete mortality (day 9, Fig. 4f). The only survivor in this treatment died on day 14, after transfer to freshwater. Treatment $\mathrm{E}$ was similar to $\mathrm{F}$, but with a later and then more rapid reduction of salinity. In this group, two megalopae metamorphosed at $4 \%$ o to firststage juveniles; these survived in freshwater to the second crab instar, but not any further (Fig. 4e).

In treatments B-E, some megalopae survived for extended periods without reaching metamorphosis. The last of these individuals died on days 33,30 and 28, respectively, after transfer to freshwater (Fig. 4). In treatments B and $\mathrm{D}$, the juvenile crabs showed reduced survival and delayed development compared to the seawater control (A). These effects of salinity stress were conspicuously stronger in treatments $\mathrm{C}$ and $\mathrm{E}$, where development did not proceed beyond the second crab stage (Fig. 4).

Figure 5 summarizes the mortality patterns in the megalopa and crab stages I-III. Lowest megalopal mortality $(44 \%)$ was observed in the seawater control, slightly higher values (differences statistically insignificant) in treatments B and D, and significantly higher mortalities in groups C, E and F (with complete mortality in F). When further survival through the first three juvenile crab instars is considered, the seawater control represents clearly the most favourable salinity condition (no juvenile mortality), followed by treatments B and D; all other conditions $(\mathrm{C}, \mathrm{E}$, 
Fig. 3 N. granulata, Experiment 2, survival (number of individuals) in a seawater control (a, constant 32\%o) and three treatments with decreasing salinities (b-d; salinity drawn to same scale, shown as shaded area below dashed line); for timing and extent of salinity reductions, see Table 1


F) did not allow for juvenile development to the crab-IV instar.

Comparison of juvenile body size (CW) shows in the first crab stage a slight but statistically significant difference between the seawater control and treatment $\mathrm{B}$, otherwise insignificant differences (Fig. 6). Clear differences in CW were detected in crab stages III and IV, with significantly larger size reached in the seawater control. Yet, it is remarkable that treatments $\mathrm{B}$ and $\mathrm{D}$ allowed for at least some successful juvenile development and growth during continuous exposure to freshwater.

\section{Discussion}

Our experimental study shows that the larvae of $N$. granulata tolerate a wide array of estuarine salinity conditions. After hatching, the zoea-I stage can survive for up to several days and, exceptionally, also moult to the second zoeal stage, at a salinity as low as $5 \%$ (Fig. 1). This extreme larval euryhalinity is based on an early expression of hyperosmoregulatory functions already at hatching (Charmantier et al. 2002). It provides the first-stage zoeae with sufficient time to leave oligohaline waters occurring in the adult habitat, using outflowing tidal surface currents (Spivak et al. 1994). Field observations from the brackish lagoon Mar Chiquita (Anger et al. 1994) suggest that the subsequent zoeal development to the megalopa stage occurs in this species in coastal marine waters, where higher and more stable salinities prevail. Reimmigration and recruitment to the adult populations occur in $N$. granulata during the megalopa stage (Luppi et al. 2002).

Interestingly, the patterns of larval dispersal observed in a physically highly variable natural environment (Anger et al. 1994) match the ontogenetic patterns of osmoregulation under constant salinity conditions in the laboratory (Charmantier et al. 2002). Compared to the fairly strong capability of hyper-osmoregulation in freshly hatched zoea-I larvae, a significantly weaker capacity was measured in the zoeal stages II-IV, followed by a substantial increase in the megalopa stage. In the latter, a strong capability of hyper-osmoregulation provides the physiological basis for reimmigration to oligohaline habitats, where most adult populations of $N$. granulata live, for instance in the Mar Chiquita lagoon. A similar correspondence between developmental changes in salinity tolerance and osmoregulation was recently observed in the Chinese mitten crab, Eriocheir sinensis (Cieluch et al. 2007). The match of ecological and physiological data suggests that larval export strategies of estuarine and some freshwaterinhabiting species (see Torres et al. 2006) are closely associated with a genetically programmed expression pattern in major osmoregulatory structures and functions. This includes the formation of ion-transporting tissues as well as synthesis of a key enzyme, $\mathrm{Na}^{+}-\mathrm{K}^{+}$-ATPase, especially in those developmental stages that are during ontogenetic migrations exposed to osmotic stress (Cieluch et al. 2007; Torres et al. 2007). 
Fig. 4 N. granulata, Experiment 3, survival (number of individuals) in a seawater control (a, constant 32\%o) and five treatments with decreasing salinities (b-f); for further explanations, see Fig. 3, Table 1
Exp. 3: exposure from Megalopa stage


Our data show that successful larval development from hatching to the megalopa stage is in $N$. granulata possible at salinities down to $10 \%$. Significantly delayed development and enhanced mortality, however, suggest that this condition is near the tolerated lower limit for continuous larval retention in estuarine habitats. Zoeal survival and development to the megalopa stage were only little affected by salinities ranging from 15 to $32 \%$, indicating that a complete export to oceanic waters with full-strength seawater is not necessary for this species. Rather, maximum survival at $25 \%$ suggests that a retention in estuarine environments with moderately reduced (polyhaline) salinities may be even more favourable for its larval development. The tolerance of brackish conditions during the larval phase should be crucially important for the largest existing population of this species, which lives in salt marshes along the Bay of Sanborombón (Argentina), on the southern shore of the Rio de la Plata estuary. In this population, the larvae cannot be exported to the open sea, but only to estuarine waters, where salinities during the reproductive season (spring and summer) range between 15 and 25\%o, both at the surface and near the bottom (Guerrero et al. 1997).

As another surprising result, our experiments showed that a limited potential for reimmigration to estuarine environments already exists in the last zoeal stage (IV). Successful moulting to the megalopa stage occurred at salinities well below $10 \%$, and further salinity reductions down to limnetic conditions did not cause immediate mortality, but still allowed for extended periods of megalopal survival. Although complete larval development through metamorphosis was impossible under these extremely stressful conditions, our observations indicate that the late larval stages of $N$. granulata are well adapted to develop also under brackish conditions. This corroborates our conclusion that the larvae of this species may tolerate a limited retention in estuarine habitats, where moderately reduced or variable salinities prevail, for instance near the mouth of the Rio de la Plata estuary (Guerrero et al. 1997).

Compared to the zoea-IV stage, the megalopa of $N$. granulata is a very strong osmoregulator (Charmantier 


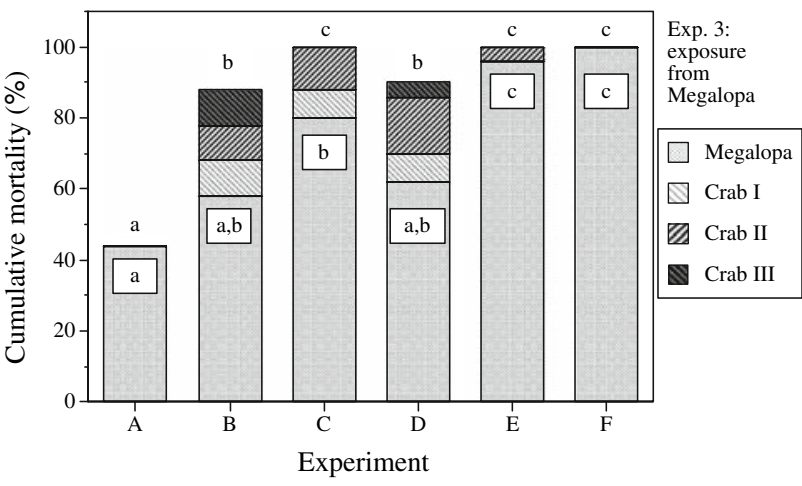

Fig. $5 N$. granulata, Experiment 3, cumulative mortality from the beginning of the megalopa stage through juvenile crab stages I-III (\%, initial $n=50$ in treatments $B-F ; n=47$ in seawater control (A). Different letters within columns indicate significant differences between salinity treatments in megalopal mortality only, those above columns refer to differences in cumulative mortality; for further explanations, see Fig. 3, Table 1

et al. 2002). Our experiments showed that its tolerance of hypo-osmotic stress was greatly enhanced by gradual acclimation to decreasing salinity, especially in treatments where this process began soon after reaching the megalopa stage. Successful metamorphosis was under such conditions possible at salinities between 6 and $10 \%$, and juvenile development continued even in freshwater. A prolonged initial development at a favourably high salinity (Exp. 3, treatments E, F) did not enhance but weaken the tolerance of subsequent hypo-osmotic stress. When salinity in these treatments was later reduced only from 32 to $10 \%$, osmotic shock caused immediate and almost complete mortality. This effect may also explain the surprisingly poor survival and development in treatment $\mathrm{C}$ as compared to $\mathrm{D}$. Although treatment D implied an earlier transfer to freshwater (i.e. a seemingly faster salinity reduction), the earlier beginning of this reduction may have been less stressful.

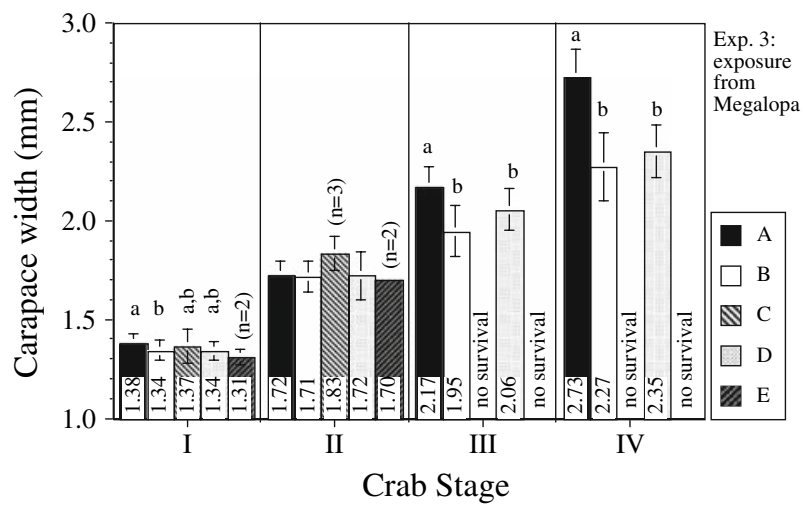

Fig. 6 . granulata, Experiment 3, growth (carapace width, mm) through juvenile crab stages I-IV (mean \pm SD). Different letters above columns indicate significant differences between salinity treatments $(A-E)$; for further explanations, see Fig. 3, Table 1
The early juvenile stages of $N$. granulata are even stronger osmoregulators than the megalopa (Charmantier et al. 2002). After gradual acclimation (in our experiments during the megalopa stage), this physiological capability allowed for successful development even in freshwater. Although crab mortality was in such treatments enhanced and growth reduced, as compared to the seawater control (Figs. 5, 6), this is a remarkable degree of euryhalinity. Together, the high adaptability of the megalopa and early juvenile crab stages are favourable preconditions for successful reimmigration to oligohaline salt marshes, where semiterrestrial conditions with dangers of desiccation, tidal seawater intrusions and freshwater inundations after rainfalls may cause extreme fluctuations in salinity and other key factors (Luppi et al. 2002; Bas et al. 2007).

Interestingly, there are also some fully marine populations of $N$. granulata, which never face hypo-osmotic conditions, for instance in the Gulf of San Matias, northern Patagonia (Bas et al. 2005, 2007). Future comparative studies of separate populations within the broad geographic range of this species should show if differential selective pressures under different salinity regimes, in concert with reproductive isolation, has led to shifts in the salinity tolerance of the larval and early juvenile stages, or to changes in their capability for acclimation to hypo-osmotic conditions (for discussion of metapopulation formation in this species, see Giménez 2003).

The detection of suitable settlement habitats by the megalopa is in $N$. granulata facilitated by a response to chemical cues from conspecific adults (Gebauer et al. 1998, 1999). Metamorphosis-stimulating effects of odors originating from the habitats of the adults have been observed also in other estuarine and freshwater-inhabiting species of crab (Gebauer et al. 2003; Anger et al. 2006). However, those cues are likely to co-occur with low or fluctuating salinities, which tend to retard rather than stimulate metamorphosis. Future experimental investigations should therefore consider the combined effects of potentially metamorphosisdelaying and accelerating factors (Anger et al. 2006) also. Such interactions may be involved in the fine-tuning of habitat choice, settlement and recruitment processes, and eventually, affect the distribution and fitness of benthic populations and communities (Giménez 2003, 2004, 2006).

Acknowledgments This research was part of a bilateral cooperation programme (MAR-8) between the Biologische Anstalt Helgoland, Germany, and the Universidad Nacional de Mar del Plata (UNMdP), Argentina. It was funded, on behalf of the German Federal Ministry of Education, Science and Technology (Berlin) and the Secretaría de Ciencia y Tecnología (Buenos Aires), by Forschungszentrum Jülich and Consejo Nacional de Investigaciones Científicas y Técnicas de la República Argentina (CONICET). ES and TL acknowledge UNMdP grants (PIP 838/98, 15/E149) and fellowships, respectively. DI was supported by Deutscher Akademischer Austauschdienst (DAAD; Bonn; Grant 3225032812) and "Conselho Nacional de Desenvolvi- 
mento Científico e Tecnológico" (Brasília, Brazil; Grants 840064/90-0 and 840167/94-6).

\section{References}

Abigail P, Moreno R, Medesani DA, Rodríguez EM (2003) Inhibition of molting by cadmium in the crab Chasmagnathus granulata (Decapoda Brachyura). Aquat Toxicol 64:155-164

Anger K (2001) The Biology of decapod crustacean larvae. Crustacean issues, vol 14. AA Balkema Publishers, Lisse

Anger K (2003) Salinity as a key parameter in the larval biology of decapod crustaceans. Inv Repr Dev 43:29-45

Anger K, Spivak E, Bas C, Ismael D, Luppi T (1994) Hatching rhythms and dispersion of decapod crustacean larvae in a brackish coastal lagoon in Argentina. Helgoländer Meeresunters 48:445466

Anger K, Torres G, Giménez L (2006) Metamorphosis of a sesarmid river crab, Armases roberti: stimulation by adult odours versus inhibition by salinity stress. Mar Freshw Behav Physiol 39:269278

Bas C, Luppi T, Spivak E (2005) Population structure of the South American estuarine crab, Chasmagnathus granulatus (Brachyura: Varunidae) near the southern limit of its geographical distribution: comparison with northern populations. Hydrobiologia 537:217-228

Bas C, Spivak ED, Anger K (2007) Seasonal and interpopulational variability in fecundity, egg size, and elemental composition (CHN) of eggs and larvae of a grapsoid crab, Chasmagnathus granulatus. Helgol Mar Res 61:doi 10.1007/s 10152-007-0070-y

Bortolus A, Laterra P, Iribarne O (2004) Crab-mediated phenotypic changes in Spartina densiflora Brong. Estuar Coast Shelf Sci 59:97-107

Boschi EE (1964) Los crustáceos decápodos Brachyura del litoral bonaerense (R. Argentina). Bol Inst Biol Mar, Mar del Plata 6:1-100

Boschi EE, Fischbach CE, Iorio MI (1992) Catálogo ilustrado de los crustáceos estomatópodos y decápodos marinos de Argentina. Frente Maritimo, Uruguay 10:7-94

Boschi EE, Scelzo MA, Goldstein B (1967) Desarrollo larval de dos especies de Crustáceos Decápodos en el laboratorio. Pachycheles haigae Rodrigues Da Costa (Porcellanidae) y Chasmagnathus granulata Dana (Grapsidae). Bol Inst Biol Mar, Mar del Plata 12:3-46

Botto F, Iribarne O, Gutierrez J, Bava J, Gagliardini A, Valiela I (2006) Ecological importance of passive deposition of organic matter into burrows of the SW Atlantic crab Chasmagnathus granulatus. Mar Ecol Progr Ser 312:201-210

Botto F, Valiela I, Iribarne O, Martinetto P, Alberti J (2005) Impact of burrowing crabs on $\mathrm{C}$ and $\mathrm{N}$ sources, control, and transformations in sediments and food webs of SW Atlantic estuaries. Mar Ecol Progr Ser 293:155-164

Castilho PC, Martins IA, Bianchini A (2001) Gill Na ${ }^{+}, \mathrm{K}^{+}$-ATPase and osmoregulation in the estuarine crab, Chasmagnathus granulata Dana, 1851 (Decapoda, Grapsidae). J Exp Mar Biol Ecol 256:215-227

Charmantier G, Giménez L, Charmantier-Daures M, Anger K (2002) Ontogeny of osmoregulation, physiological plasticity, and larval export strategy in the grapsid crab Chasmagnathus granulata (Crustacea, Decapoda). Mar Ecol Progr Ser 229:185-194

Cieluch U, Anger K, Charmantier-Daures M, Charmantier G (2007) Osmoregulation and immunolocalization of $\mathrm{Na}^{+} / \mathrm{K}^{+}$-ATPase during the ontogeny of the mitten crab Eriocheir sinensis (Decapoda, Grapsoidea). Mar Ecol Progr Ser 329:169-178

Daleo P, Ribeiro P, Iribarne O (2003) The SW Atlantic burrowing crab Chasmagnathus granulatus Dana affects the distribution and survival of the fiddler crab Uca uruguayensis Nobili. J Exp Mar Biol Ecol 291:255-267

de Oliveira UO, da Rosa Araujo AS, Bello-Klein A, da Silva RSM, Kucharski LC (2005) Effects of environmental anoxia and different periods of reoxygenation on oxidative balance in gills of the estuarine crab Chasmagnathus granulata. Comp Bioch Physiol B 140:51-57

Delorenzi A, Dimant B, Frenkel L, Nahmod VE, Nässel DR, Maldonado H (2000) High environmental salinity induces memory enhancement and increases levels of brain angiotensin-like peptides in the crab Chasmagnathus granulatus. J Exp Biol 203:3369-3379

Gebauer P, Paschke K, Anger K (1999) Costs of delayed metamorphosis: reduced growth and survival in early juveniles of an estuarine grapsid crab, Chasmagnathus granulata. J Exp Mar Biol Ecol 238:271-281

Gebauer P, Paschke K, Anger K (2003) Delayed metamorphosis in decapod crustaceans: evidence and consequences. Rev Chilena Hist Nat 76:169-175

Gebauer P, Walter I, Anger K (1998) Effects of substratum and conspecific adults on the metamorphosis of Chasmagnathus granulata (Dana) (Decapoda: Grapsidae) megalopae. J Exp Mar Biol Ecol 223:185-198

Giménez L (2002) Effects of prehatching salinity and initial larval biomass on survival and duration of development in the zoea 1 of the estuarine crab, Chasmagnathus granulata, under nutritional stress. J Exp Mar Biol Ecol 270:93-110

Giménez L (2003) Potential effects of physiological plastic responses to salinity on population networks of the estuarine crab Chasmagnathus granulata. Helgoland Mar Res 56:265-273

Giménez L (2004) Marine community ecology: importance of traitmediated effects propagating through complex life cycles. Mar Ecol Progr Ser 283:303-310

Giménez L (2006) Phenotypic links in complex life cycles: conclusions from studies with decapod crustaceans. Integr Comp Biol 46:615-622

Giménez L, Anger K (2003) Larval performance in an estuarine crab, Chasmagnathus granulata, is a consequence of both larval and embryonic experience. Mar Ecol Progr Ser 249:251-264

Giménez L, Anger K, Torres G (2004) Linking life history traits in successive phases of a complex life cyle: effects of larval biomass on early juvenile development in an estuarine crab, Chasmagnathus granulata. Oikos 104:570-580

Giménez L, Torres G (2002) Larval growth in the estuarine crab Chasmagnathus granulata: the importance of salinity experienced during embryonic development, and the initial larval biomass. Mar Biol 141:877-885

Guerrero RA, Lasta CA, Acha EM, Mianzán HW, Framiñan MB (1997) Atlas hidrográfico del Río de la Plata. Publicaciones Especiales INIDEP, Mar del Plata, Argentina

Halperin J, Genovese G, Tresguerres M, Luquet CM (2004) Modulation of ion uptake across posterior gills of the crab Chasmagnathus granulatus by dopamine and cAMP. Comp Biochem Physiol A 139:103-109

Iribarne O, Botto F, Martinetto P, Gutierrez JL (2000) The role of burrows of the SW Atlantic intertidal crab Chasmagnathus granulata in trapping debris. Mar Poll Bull 40:1057-1062

Iribarne O, Bruschetti M, Escapa M, Bava J, Botto F, Gutierrez J, Palomo G, Delhey K, Petracci P, Gagliardini A (2005) Small- and large-scale effect of the SW Atlantic burrowing crab Chasmagnathus granulatus on habitat use by migratory shorebirds. J Exp Mar Biol Ecol 315:87-101

Ituarte RB, Spivak ED, Luppi TA (2004) Female reproductive cycle of the Southwestern Atlantic estuarine crab Chasmagnathus granulatus (Brachyura: Grapsoidea: Varunidae). Sci Mar 68:127-137 
Locatelli F, LaFourcade C, Maldonado H, Romano A (2001) Characterisation of cAMP-dependent protein kinase isoforms in the brain of the crab Chasmagnathus. J Comp Physiol B 171:33-40

Luppi TA, Spivak ED, Anger K, Valero JL (2002) Patterns and processes of Chasmagnathus granulata and Cyrtograpsus angulatus (Brachyura: Grapsidae) recruitment in Mar Chiquita Coastal Lagoon, Argentina. Est Coast Shelf Sci 55:287-297

Luquet CM, Genovese G, Rosa GA, Pellerano GN (2002) Ultrastructural changes in the gill epithelium of the crab Chasmagnathus granulatus (Decapoda: Grapsidae) in diluted and concentrated seawater. Mar Biol 141:753-760

Maciel FE, Rosa CE, Santos EA, Monserrat JM, Nery LEM (2004) Daily variations in oxygen consumption, antioxidant defenses, and lipid peroxidation in the gills and hepatopancreas of an estuarine crab. Can J Zool 82:1871-1877

Marqueze A, Kucharski LC, da Silva RSM (2006) Effects of anoxia and post-anoxia recovery on carbohydrate metabolism in the jaw muscle of the crab Chasmagnathus granulatus maintained on carbohydrate-rich or high-protein diets. J Exp Mar Biol Ecol 332:198-205

Martinetto P, Iribarne O, Palomo G (2005) Effect of fish predation on intertidal benthic fauna is modified by crab bioturbation. J Exp Mar Biol Ecol 318:71-84

Martinetto P, Ribeiro P, Iribarne O (2007) Changes in distribution and abundance of juvenile fishes in intertidal soft sediment areas dominated by the burrowing crab Chasmagnathus granulatus. Mar Freshw Res 58:194-203

Medesani DA, Lopez Greco LS, Rodríguez EM (2004a) Disruption of endocrine regulation of glycemia levels by cadmium and copper in the estuarine crab Chasmagnathus granulata. Bull Envir Contam Toxicol 73:942-946

Medesani DA, Lopez Greco LS, Rodríguez EM (2004b) Interference of cadmium and copper with the endocrine control of ovarian growth, in the estuarine crab Chasmagnathus granulata. Aquat Toxicol 69:165-174

Menone ML, Miglioranza KSB, Iribarne O, Aizpun de Moreno JE, Moreno VJ (2004) The role of burrowing beds and burrows of the SW Atlantic intertidal crab Chasmagnathus granulata in trapping organochlorine pesticides. Mar Poll Bull 48:240-247

Morgan SG (1995) Life and death in the plankton: larval mortality and adaptation. In: McEdward LR (ed) Ecology of marine invertebrate larvae. CRC Press, Boca Raton, FL, pp 279-321

Oliva D, Medan V, Tomsic D (2007) Escape behavior and neuronal responses to looming stimuli in the crab Chasmagnathus granulatus (Decapoda: Grapsidae). J Exp Biol 210:865-880

Oliveira GT, Eichler P, Rossi IC, da Silva RSM (2004) Hepatopancreas gluconeogenesis during anoxia and post-anoxia recovery in
Chasmagnathus granulata crabs maintained on high-protein or carbohydrate-rich diets. J Exp Zool 301A:240-248

Pestana D, Ostrensky A (1995) Occurrence of an alternative pathway in the larval development of the crab Chasmagnathus granulata Dana, 1851 under laboratory conditions. Hydrobiologia 306:3340

Romano A, Locatelli F, Freudenthal R, Merlo E, Feld M, Ariel P, Lemos D, Federman N, Fustinana MS (2006) Lessons from a crab: molecular mechanisms in different memory phases of Chasmag nathus. Biol Bull 210:280-288

Ruffino ML, Telles MD, D'Incao F (1994) Reproductive aspects of Chasmagnathus granulata Dana, 1851 (Decapoda, Grapsidae) in the Patos Lagoon Estuary-Brazil. Nauplius 2:43-52

Sakai K, Türkay M, Yang S-L (2006) Revision of the Helice/Chasmagnathus complex (Crustacea: Decapoda: Brachyura). Abh Senckenb Naturforsch Ges 565:1-76

Schein V, Chitto ALF, Etges R, Kucharski LC, van Wormhoudt A, Da Silva RSM (2005a) Effects of hypo- or hyperosmotic stress on gluconeogenesis, phosphoenolpyruvate carboxykinase activity, and gene expression in jaw muscle of the crab Chasmagnathus granulata: seasonal differences. J Exp Mar Biol Ecol 316:203-212

Schein V, Fernandes Chitto AL, Etges R, Kucharski LC, van Wormhoudt A, Da Silva RSM (2005b) Effect of hyper or hypo-osmotic conditions on neutral amino acid uptake and oxidation in tissues of the crab Chasmagnathus granulata. Comp Biochem Physiol B 140:561-567

Sokal RR, Rohlf FJ (1995) Biometry. The principles and practice of statistics in biological research, 3rd edn. Freeman, San Francisco, CA

Spivak ED, Anger K, Luppi T, Bas C, Ismael D (1994) Distribution and habitat preferences of two grapsid crab species in Mar Chiquita Lagoon (Province of Buenos Aires, Argentina). Helgoländer Meeresunters 48:59-78

Strathmann RR (1982) Selection for retention or export of larvae in estuaries. In: Kennedy VS (ed) Estuarine comparisons. Academic Press, San Diego, CA, pp 521-535

Tomsic D, de Astrada MB, Sztarker J (2003) Identification of individual neurons reflecting short- and long-term visual memory in an arthropod. J Neurosci 23:8539-8546

Torres G, Anger K, Giménez L (2006) Effects of reduced salinities on metamorphosis of a freshwater-tolerant sesarmid crab, Armases roberti: is upstream migration in the megalopa stage constrained by increasing osmotic stress? J Exp Mar Biol Ecol 338:134-139

Torres G, Charmantier-Daures M, Chifflet S, Anger K (2007) Effects of long-term exposure to different salinities on the location and activity of $\mathrm{Na}^{+}-\mathrm{K}^{+}$-ATPase in the gills of juvenile mitten crab, Eriocheir sinensis. Comp Biochem Physiol A 147:460-465 